\title{
Development of Heated Ore Addition Technology Using Burner in Chromium Ore Smelting Reduction Converter
}

\author{
Goro OKUYAMA, ${ }^{1 * *}$ Futoshi OGASAWARA, ${ }^{1)}$ Yuichi UCHIDA, ${ }^{1)}$ Yuji MIKI, ${ }^{1)}$ Yasuo $\mathrm{KISHIMOTO}^{2)}$ Hisashi OGAWA ${ }^{3)}$ \\ and Yohei KANEKO ${ }^{4)}$
}

1) JFE Steel Corporation, Steel Research Laboratory, 1, Kawasaki-cho, Chuo-ku, Chiba, 260-0835 Japan.

2) Formerly JFE Steel Corporation, Steel Research Laboratory. Now at Ministry of Education, Culture, Sports, Science and Technology, 3-2-2, Kasumigaseki, Chiyoda-ku, Tokyo, 100-8959 Japan.

3) Formerly JFE Steel Corporation, East Japan Works. Now at West Japan Works, 1, Kokan-cho, Fukuyama, Hiroshima, 7218510 Japan.

4) JFE Steel Corporation, East Japan Works, 1, Kawasaki-cho, Chuo-ku, Chiba, 260-0835 Japan.

(Received on November 4, 2014; accepted on February 25, 2015; originally published in Tetsu-to-

Hagané, Vol. 100, 2014, No. 4, pp. 530-538)

\begin{abstract}
In order to increase the heat efficiency of the chromium ore smelting reduction furnace, a heated ore addition technology using a burner in the converter was developed. 5 ton scale pilot converter tests were conducted. Based on the results of the pilot converter tests, this technology has been applied to the actual process. The results are summarized as follows:

1) Compared with the conventional process (without burner), the amount of effective heat transfer increased by $18 \%$ with addition of heated ore using the burner in 5 ton converter.

2) A decrease in the off-gas temperature and reduction of the thermal load on the refractory were also confirmed in 5 ton converter.

3) The heat transfer ratio of burner combustion with addition of heated ore increased up to about $90 \%$, depending on the increase of the ore feeding rate in 5 ton converter.

4) From the results of a numerical simulation, it was revealed that the total sensible heat of all particles increases as the ore feeding rate increases. As a result, the ore particles heated by the flame function as a medium of heat transfer from the flame to the molten metal and slag.

5) This technology was applied to an actual smelting reduction furnace at JFE Steel East Japan Works (Chiba). As in the tests with 5 ton converter, the heat transfer ratio of burner combustion with addition of heated ore was about $90 \%$. The supplied energy per unit of chromium ore added to the furnace decreased by $17 \%$.
\end{abstract}

KEY WORDS: smelting reduction; converter; burner; combustion: heat transfer; lance.

\section{Introduction}

The chromium ore smelting reduction method has been adopted in the stainless steelmaking process in JFE Steel Corporation. ${ }^{1-3)}$ Chromium ore is used as the chromium source for stainless steel as an alternative to chromium alloys. In order to improve flexibility in the choice of chromium resources, it is important to increase the amount of chromium ore that can be used in the smelting reduction furnace. In this process, the chromium oxide in the ore is reduced by carbonaceous materials which are added in the furnace. As the reaction is endothermic, it is necessary to increase the heat supply to the furnace in order to increase use of chromium ore. ${ }^{4)}$

A variety of techniques have been examined with the aim of increasing the heat supply to the converter. These include techniques for increasing the oxygen gas supply to

\footnotetext{
* Corresponding author: E-mail: g-okuyama@jfe-steel.co.jp

DOI: http://dx.doi.org/10.2355/isijinternational.55.1390
}

the converter and for enhancing post-combustion. ${ }^{5-11)}$ However, increasing of the amount of oxygen gas supplied to the converter increases the amount of dust generated from the hot metal, which reduces the yield of chromium and iron. ${ }^{5}$ As techniques for enhancing post-combustion operation, use of a higher lance height and the development of a nozzle shape for obtaining a soft blow jet have been proposed. ${ }^{6-11)}$ Although enhanced post-combustion increases heat generation in the converter, the efficiency of post-combustion heat transfer to the molten metal and slag is low.

A technology using burner combustion was considered as an alternative heat source for decarburization heat and post-combustion heat. However, if the hot metal is simply heated by the burner flame, combustion occurs in the space above the melt in the same manner as in post-combustion. Therefore, the efficiency of heat transfer to the hot metal with this technique is also considered to be low. To overcome this problem, the authors investigated a method for efficiently transferring the combustion heat of the burner to the hot metal by heating chromium ore, which is a granular 
raw material, in the burner flame and feeding the heated ore to the furnace through the flame.

In a previous report, ${ }^{12}$ ) we showed that heated ore fed through the burner functions as a heat transfer medium for transfer of burner combustion heat to the hot metal, enabling efficient transfer of burner combustion heat to the metal bath in a 4 ton melting furnace.

In the present study, we conducted tests of chromium ore smelting reduction with a heated ore addition lance using the burner in a 5 ton scale pilot top and bottom blown converter, and clarified the burner combustion heat transfer improvement effect of the heated ore addition lance using the burner based on a heat balance analysis of the 5 ton converter.

Based on the results of the pilot converter tests, this technology was applied to the actual process.

\section{5 Ton Scale Pilot Converter Tests of Chromium Ore Smelting Reduction Using Burner Lance}

\subsection{Experimental Method}

Figure 1 shows schematic diagrams of the 5 ton pilot converter and burner lance. The top main lance for blowing refining oxygen gas has four straight nozzles, and the lance height is $1.5 \mathrm{~m}$, this height being defined as the distance

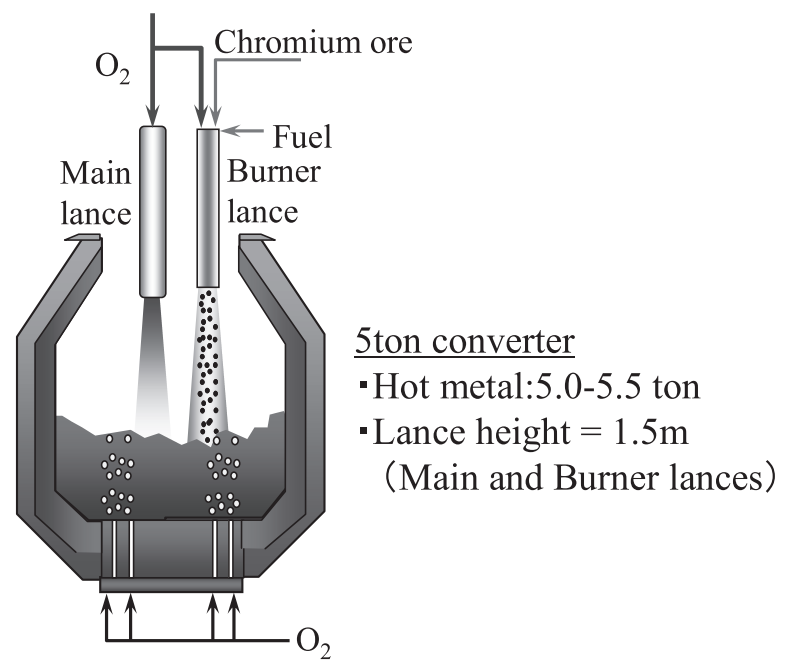

Fig. 1. Schematic diagram of experimental apparatus using $5 \mathrm{t}$ converter. from the tip of the lance to the molten metal.

The chromium ore feeding lance supplies ore through the center hole and propane gas as a fuel and oxygen gas as a combustion improver through the outer nozzles. The height of the chromium ore feeding lance is $1.5 \mathrm{~m}$, which is the same as that of the top main lance. The chromium ore feeding rate in these tests was $15-25 \mathrm{~kg} / \mathrm{min}$. The average diameter of the chromium ore was approximately $200 \mu \mathrm{m}$, and the ore was the same as that used in the actual converter.

Table 1 shows the experimental conditions. The total flow rate of the top and bottom blowing oxygen gas and combustion improver oxygen gas was $20-26 \mathrm{Nm}^{3} / \mathrm{min}$. The flow rate of the propane was $0.5 \mathrm{Nm}^{3} / \mathrm{min}$, and that of the combustion improver oxygen gas was $3 \mathrm{Nm}^{3} / \mathrm{min}$.

In order to investigate the heat transfer behavior of burner combustion heat to the molten metal and slag, pilot converter tests were conducted by the three chromium ore feeding methods shown below.

1) Feeding chromium ore by the feeding lance without burner combustion, which corresponds to the conventional method. (In this method, the propane gas and combustion improver oxygen gas flow rates were both $0 \mathrm{Nm}^{3} / \mathrm{min}$.)

2) Feeding heated chromium ore through the burner flame by the feeding lance, which was called the heated ore feeding method.

3) Addition of chromium ore from outside the burner flame, which was called the unheated ore addition method. In this method, chromium ore packed in bags was added from the top of the converter during burner operation.

\subsection{Experimental Results and Discussion}

2.2.1. Heat Transfer Ratio with Heated Chromium Ore Feeding Method

Figure 2 shows an example of the blowing pattern. After charging hot metal into the converter, the temperature of the hot metal was increased to $1550-1580^{\circ} \mathrm{C}$ by top and bottom blowing oxygen without using the burner. Next, the chromium ore smelting reduction process was conducted. During the smelting reduction period, chromium ore and coke were fed into the converter. The chromium ore feeding lance with the burner was used only during the smelting reduction period.

The hot metal temperature was measured periodically,

Table 1. Experimental conditions.

\begin{tabular}{cccccccl}
\hline No. & $\begin{array}{c}\text { Total } \mathrm{O}_{2} \\
\text { gas }\end{array}$ & $\begin{array}{c}\text { Top and } \\
\text { bottom } \mathrm{O}_{2}\end{array}$ & $\begin{array}{c}\text { Burner } \\
\mathrm{C}_{3} \mathrm{H}_{8}\end{array}$ & $\begin{array}{c}\text { Burner } \\
\mathrm{O}_{2}\end{array}$ & $\begin{array}{c}\text { Total } \\
\text { Cr Ore }\end{array}$ & $\begin{array}{c}\text { Heated } \\
\text { Cr Ore }\end{array}$ & \\
\cline { 2 - 6 } $\mathrm{Nm}^{3} / \mathrm{min}$ & $\mathrm{Nm}^{3} / \mathrm{min}$ & $\mathrm{Nm}^{3} / \mathrm{min}$ & $\mathrm{Nm}^{3} / \mathrm{min}$ & $\mathrm{kg} / \mathrm{min}$ & $\mathrm{kg} / \mathrm{min}$ & \\
\hline 1 & 23 & 23 & 0 & 0 & 20 & 0 & Without burner \\
2 & 20 & 20 & 0 & 0 & 16 & 0 & Without burner \\
3 & 23 & 20 & 0.5 & 3 & 15 & 0 & With burner No heated ore \\
4 & 23 & 20 & 0.5 & 3 & 16 & 7 & With burner \\
5 & 23 & 20 & 0.5 & 3 & 15 & 15 & With burner \\
6 & 23 & 20 & 0.5 & 3 & 15 & 15 & With burner \\
7 & 23 & 20 & 0.5 & 3 & 23 & 23 & With burner \\
8 & 20 & 17 & 0.5 & 3 & 16 & 16 & With burner \\
9 & 26 & 23 & 0.5 & 3 & 25 & 25 & With burner \\
\hline
\end{tabular}


and the ore feeding rate was adjusted in order to keep the hot metal temperature constant.

Figure 3 shows the relationship between the calorific value in the furnace and the amount of effective heat transfer. The calorific value in the furnace is the sum of decarburization $\left(\mathrm{C}+1 / 2 \mathrm{O}_{2} \rightarrow \mathrm{CO}\right)$ heat, post-combustion $\left(\mathrm{CO}+1 / 2 \mathrm{O}_{2} \rightarrow \mathrm{CO}_{2}\right)$ heat and burner combustion heat, and the amount of heat transfer is the sum of the sensible heat increment of the hot metal and slag and the reduction heat of the chromium ore. Post-combustion heat was estimated from the amount of oxygen that was not used for the decarburization reaction. The amount of oxygen used for the decarburization reaction was estimated from the result of another decarburization experiment under the same oxygen blowing condition as in the smelting reduction process in the 5 ton converter. The effective heat transfer ratios of the calorific value in the furnace are also shown in this figure.

In comparison with the conventional method, the amount of heat transfer is higher and the heat transfer ratio increases when feeding heated chromium ore through the burner flame. However, the amount of effective heat transfer in the unheated ore addition method is smaller than that in the conventional method.

Figure 4 shows the relationship between the heated ore feeding rate and the amount of effective heat transfer at a $23 \mathrm{Nm}^{3} /$ min total oxygen flow rate.

The amount of effective heat transfer when feeding heated chromium ore through the burner flame increases

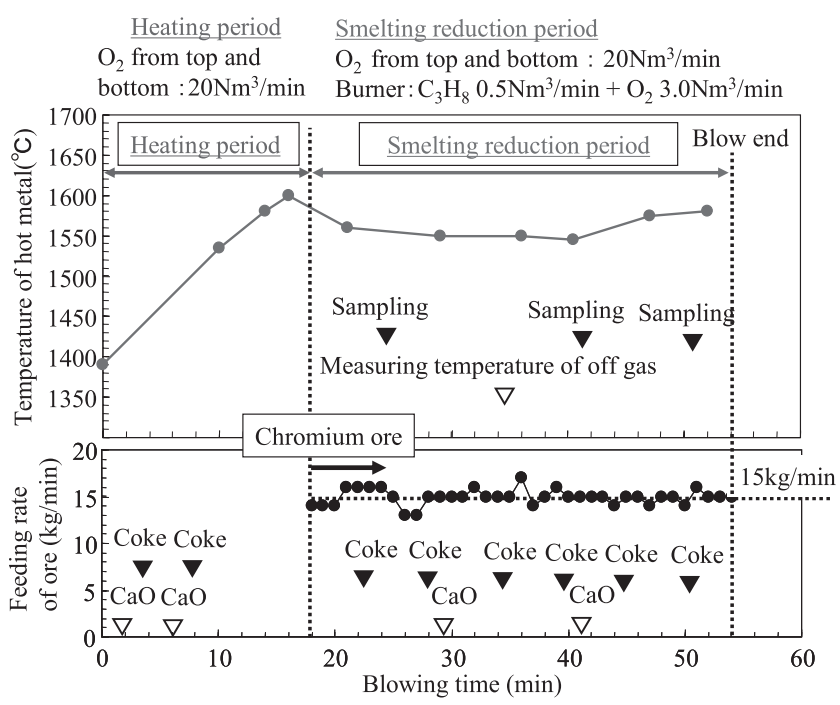

Fig. 2. Example of experimental process pattern.

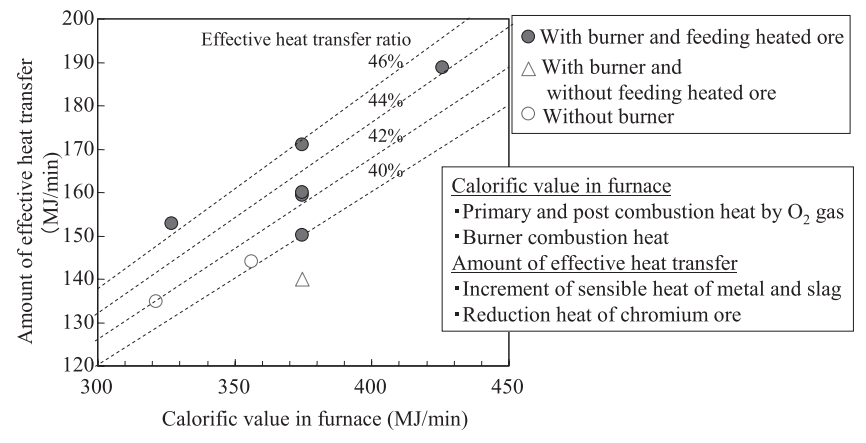

Fig. 3. Relationship between calorific value in furnace and amount of effective heat transfer. as the heated ore feeding rate increases. When the heated ore feeding rate is $22 \mathrm{~kg} / \mathrm{min}$, the amount of effective heat transfer increases by $18 \%$ compared with the conventional method. The amount of effective heat transfer by the unheated ore addition method, in which the heated ore feeding rate by the burner was $0 \mathrm{~kg} / \mathrm{min}$, was slightly lower than that by the conventional method.

Figure 5 shows the heat balances in the smelting reduction period of the conventional and heated ore feeding methods. The output heat of the heat balance is the sum of the increment of the sensible heat of the hot metal and slag, the reduction heat of the ore and the sensible heat of the off-gas, assuming the off-gas temperature is the same as the temperature of the molten metal. Unknown heat between the input and output heats is defined as superheat. ${ }^{5)}$

As the amount of top blown oxygen in operation with the burner decreases, the heats of the decarburization reaction and the post-combustion reaction decrease. However, the calorific value in the furnace increases by $18 \mathrm{MJ} / \mathrm{min}$ compared with the conventional method.

On the other hand, when feeding heated chromium ore through the burner flame, the amount of effective heat transfer increases by $26 \mathrm{MJ} / \mathrm{min}$, the sensible heat of the off-gas decreases by $1 \mathrm{MJ} / \mathrm{min}$ and the superheat decreases by $7 \mathrm{MJ} / \mathrm{min}$.

From these results, the effective heat transfer by feeding heated ore through the burner increases by more than 18 $\mathrm{MJ} / \mathrm{min}$, which corresponds to the increment of input heat.

Figure 6 shows the relationship between the heated ore feeding rate and the heat transfer ratio defined by Eq. (1). The equation proposed by Matsuo et al. ${ }^{6)}$ considered only

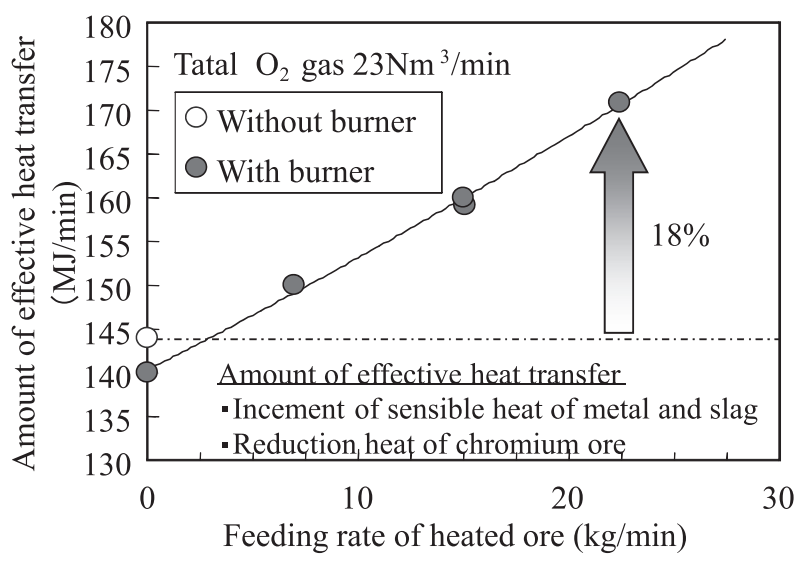

Fig. 4. Relationship between heated ore feeding rate and amount of effective heat transfer ratio.
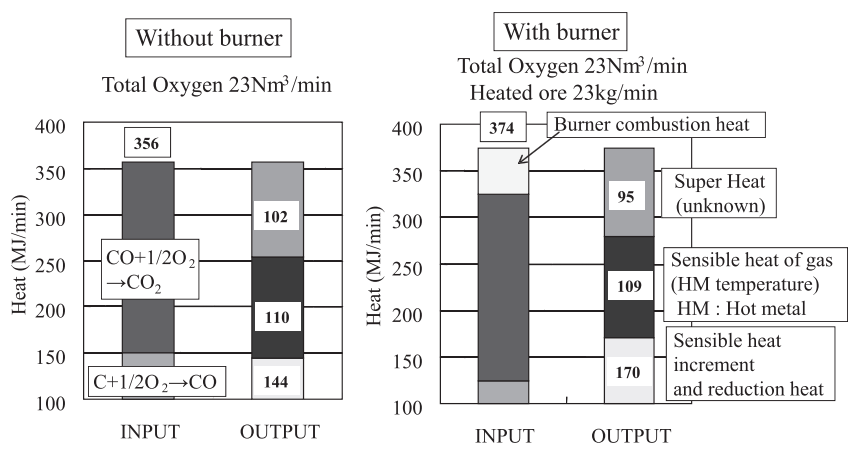

Fig. 5. Comparison of heat balance with and without burner. 
post-combustion heat, but in the present study, the denominator on the right side in Eq. (1) is defined as the sum of the post-combustion heat and burner combustion heat.

In comparison with the conventional method, the heat transfer ratio when feeding heated ore through the burner increases as the feeding rate increases.

From these results, the heated ore feeding method with the burner is a process that provides a higher heat transfer ratio than that of the conventional method using only top and bottom blown oxygen.

Heat transfer ratio $(\%)$

$=\left(1-\frac{\text { Super heat }}{\text { Post combustion }+ \text { Burner combustion heat }}\right) \times 100$

\subsubsection{Superheat of Off-gas with Burner}

In the above, the heat transfer to the hot metal and slag was analyzed. Next, the superheat when using the burner is discussed.

Figure 7 shows the relationship between the heated ore feeding rate and the superheat at the total oxygen gas flow rate of $23 \mathrm{Nm}^{3} / \mathrm{min}$.

The superheat when feeding heated ore through the burner decreases as the heated ore feeding rate increases, but

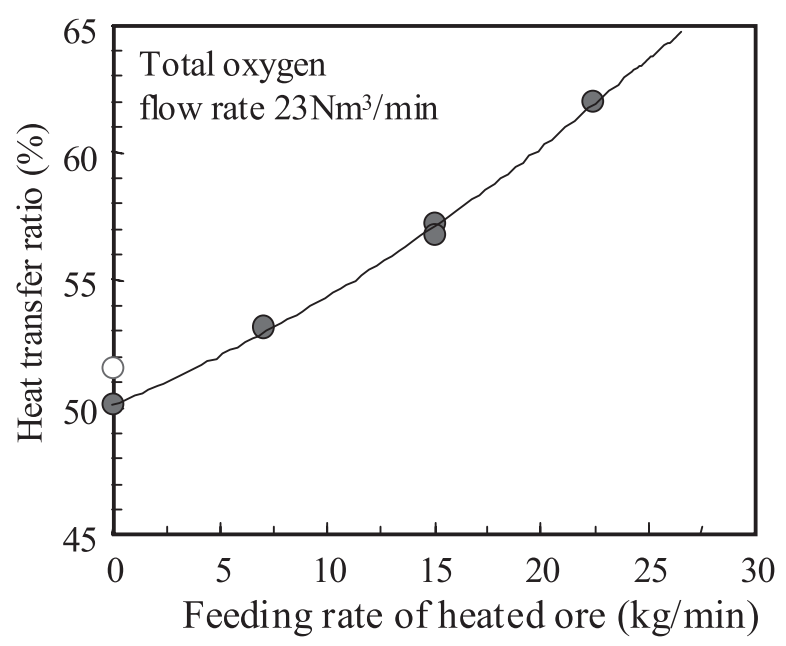

Fig. 6. Relationship between heated ore feeding rate and heat transfer ratio.

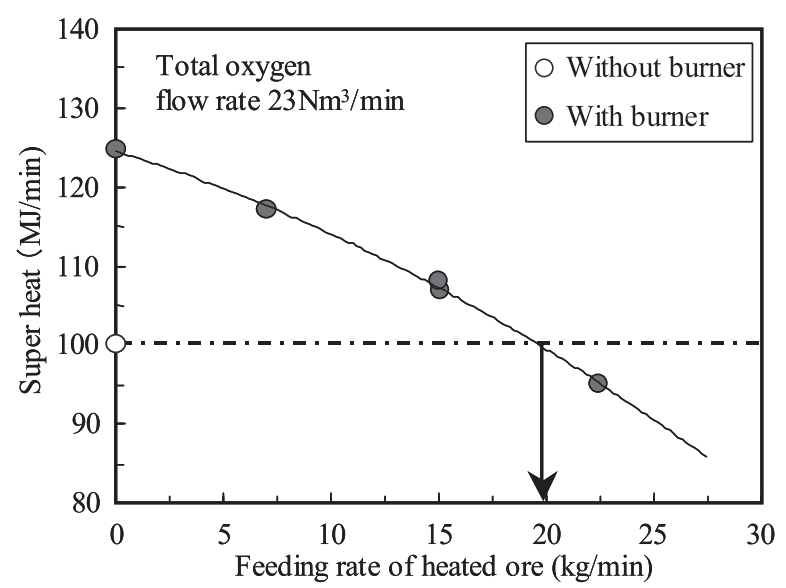

Fig. 7. Relationship between heated ore feeding rate and superheat. when the feeding rate is less than $20 \mathrm{~kg} / \mathrm{min}$, the superheat is larger than that with the conventional method without using the burner. This indicates that the temperature of the off-gas and the thermal load on the converter refractory under the condition that the feeding rate was less than $20 \mathrm{~kg} / \mathrm{min}$ are higher than those in the conventional method.

Figure 8 shows the influence of the heated ore feeding rate on the off-gas temperature, and Fig. 9 shows the influence of the heated ore feeding rate on the temperature increase rate of the refractory. The off-gas temperature was measured by the sub-lance, which was held at $-1 \mathrm{~m}$ from the top of the converter to measure the ambient temperature. The temperature of the refractory was measured with thermocouples at points $100 \mathrm{~mm}$ and $150 \mathrm{~mm}$ from the operating surface of the refractory.

With a smaller heated ore feeding rate with the burner, the temperature of the off-gas and the temperature increase rate of the refractory were higher than those of the conventional method without the burner. These results indicate that the thermal load on the converter refractory is higher at smaller heated ore feeding rates with the burner.

From the above, it is necessary to increase the heated ore feeding rate in order to decrease the thermal load on the refractory.

Figure 10 shows the relationship between the heated ore feeding rate and the heat transfer ratio of post-combustion

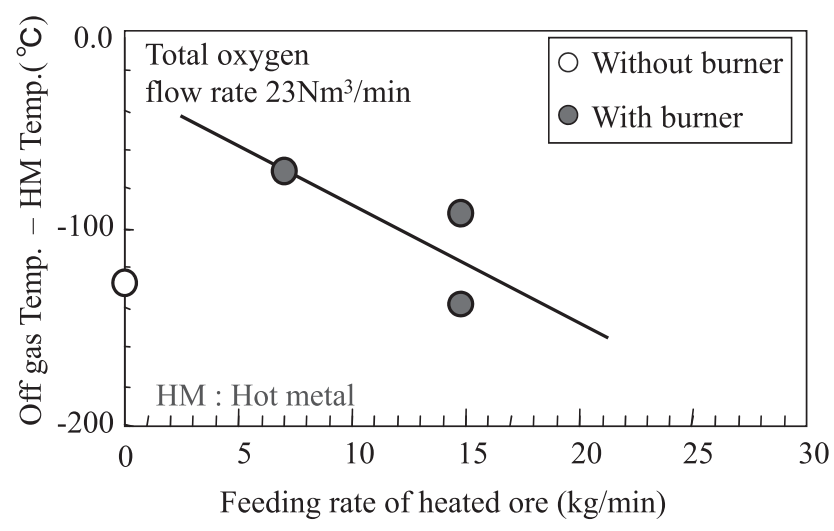

Fig. 8. Influence of heated ore feeding rate on temperature of offgas.

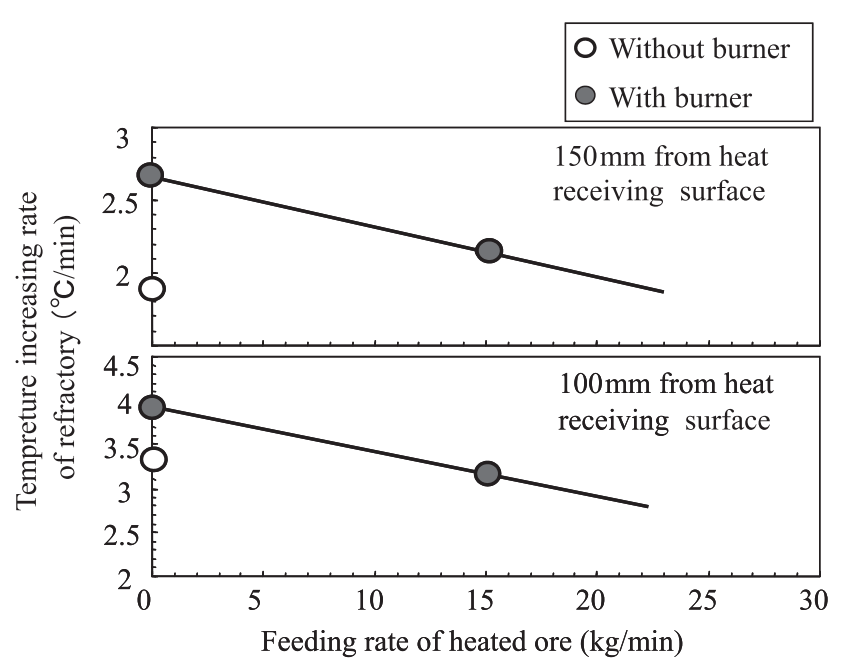

Fig. 9. Relationship between heated ore feeding rate and temperature increase rate of refractory. 


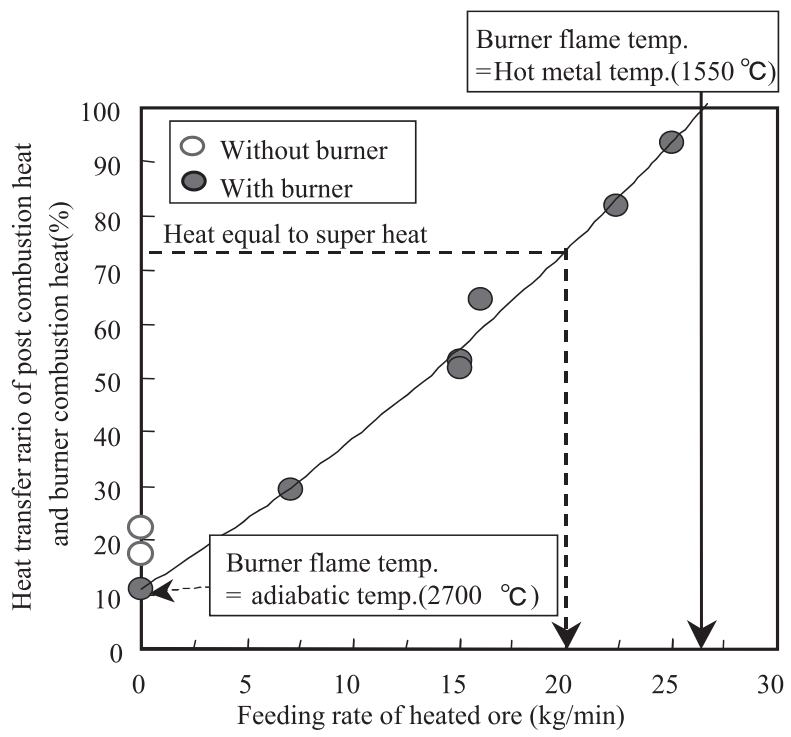

Fig. 10. Heat transfer ratio of post-combustion and burner combustion heat against feeding rate of heated ore.

heat and burner combustion heat. The heat transfer ratio of post-combustion heat and burner combustion heat is calculated as described below.

The total heat transfer is the effective heat transfer ' $Q$ ' in Figs. 3 and 4. Heat transfer ' $Q_{1}$ ' by decarburization, ' $Q_{2}$ ' by post-combustion and ' $\mathrm{Q}_{3}$ ' by burner combustion are defined as shown in Eqs. (2)-(4), respectively. $\eta_{\mathrm{PCR}}$ and $\eta_{\text {Burner }}$ indicate the heat transfer efficiency of post-combustion heat and burner combustion heat, respectively. The temperature of the off-gas is supposed to be equal to the temperature of the hot metal. The amount of CO gas in ' $\mathrm{Q}_{1}$ ' is obtained from the difference between the amount of $\mathrm{CO}$ gas formed from the decarburization reaction and that consumed by the post-combustion reaction.

As the decarburization rate is independent of use of the burner, it is considered that the post-combustion rate by top blown oxygen gas is also independent of the burner. From the above, the heat transfer efficiency of post-combustion $\eta_{\mathrm{PCR}}$ can be considered as a constant value.

$$
\begin{aligned}
& \mathrm{Q}_{1}=\text { 'Decarburization heat' } \\
& \text { - 'Sensible heat of off-gas (CO)' } \\
& \mathrm{Q}_{2}=\text { \{'Post combustion heat' } \\
& \text { - 'Sensible heat of off-gas } \left.\left(\mathrm{CO}_{2}\right){ }^{\prime}\right\} \times \eta_{\mathrm{PCR}} \ldots \text {... } \\
& \mathrm{Q}_{3}=\{\text { 'Burner combustion heat' } \\
& \text { - 'Sensible heat of off-gas } \left.\left(\mathrm{CO}_{2}, \mathrm{H}_{2} \mathrm{O}\right) \text { ' }\right\} \times \eta_{\text {Burner }}
\end{aligned}
$$

Without the burner, the heat balance is as shown in Eq. (5).

$$
\mathrm{Q}=\mathrm{Q}_{1}+\mathrm{Q}_{2}
$$

$\eta_{\mathrm{PCR}}$ can be calculated by substituting Eqs. (3) and (2) into Eq. (5).

With the burner, the heat balance is as shown in Eq. (6).

$$
\mathrm{Q}=\mathrm{Q}_{1}+\mathrm{Q}_{2}+\mathrm{Q}_{3}
$$

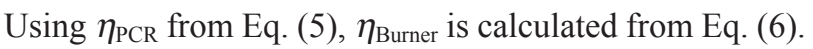

From the results in Fig. 10, the heat transfer ratio of postcombustion $\eta_{\mathrm{PCR}}$ is approximately $20 \%$.

At a heated ore feeding rate of $0 \mathrm{~kg} / \mathrm{min}$, the heat transfer
Total Oxygen $23 \mathrm{Nm}^{3} / \mathrm{min}$

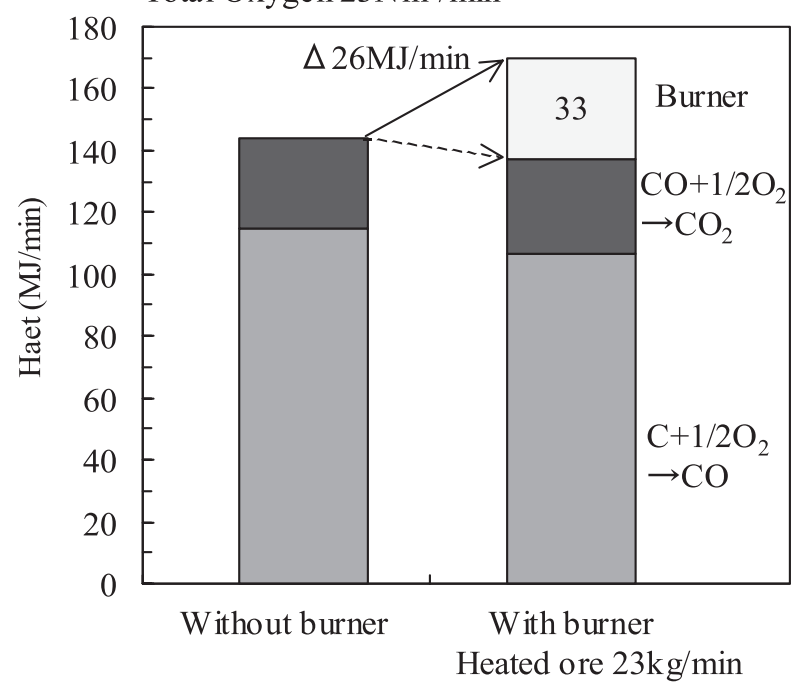

Fig. 11. Comparison of breakdown of amount of heat transfer with burner and without burner.

ratio of post-combustion is $10 \%$, but as the heated ore feeding rate increases, the heat transfer ratio of burner combustion also increases, reaching a maximum of $94 \%$.

When using the burner, the superheat at a heated ore feeding rate of more than $20 \mathrm{~kg} / \mathrm{min}$ is lower than that with the conventional method, as shown in Fig. 7.

Figure 10 shows that the superheat of the burner is lower than that in the conventional method when the heat transfer ratio of burner combustion is more than $73 \%$. The feeding rate at which the heat transfer ratio reaches $100 \%$ is estimated to be $26.5 \mathrm{~kg} / \mathrm{min}$. In this case, the temperature of the burner combustion gas is identical with that of the molten metal.

Figure 11 shows a comparison of the breakdown of the heat transfer with and without the burner shown in Fig. 5. With the burner, the decarburization and post-combustion heats decrease as the flow rate of the top and bottom blowing oxygen decreases. However, since the increment of heat transfer by burner combustion, which is $33 \mathrm{MJ} / \mathrm{min}$, is larger than the decrements of the heat of decarburization and heat of post-combustion, effective heat transfer increases by 26 $\mathrm{MJ} / \mathrm{min}$ in the heated ore feeding method with the burner.

\subsubsection{Numerical Simulation of Heat Transfer Behavior between Combustion Gas and Ore Particle}

In order to discuss the experimental results presented in the previous section, the behavior of heat transfer from the high temperature combustion gas to an ore particle was analyzed by numerical calculations. ${ }^{12)}$

The combustion gas temperature and particle temperature were calculated by calculating the following and coupling the respective results.

1) Calculation of combustion gas temperature by equilibrium calculation

2) Calculation of particle temperature due to heat transfer between combustion gas and particle

3) Calculation of particle heating time by equation of motion for particle

As the flame temperature of the combustion gas, considering the equilibrium of the 8 components $\left(\mathrm{CO}, \mathrm{CO}_{2}, \mathrm{O}_{2}, \mathrm{H}_{2}\right.$, 
$\left.\mathrm{H}_{2} \mathrm{O}, \mathrm{OH}, \mathrm{H}, \mathrm{O}\right)$ which form the combustion gas $\mathrm{C}_{3} \mathrm{H}_{8}$ by reaction with oxygen, the combustion gas temperature under the adiabatic condition with the outside of the system was calculated by a trial-and-error method by using the equilibrium equations shown in Eqs. (7) to (11) and the enthalpy balance equation of gas in Eq. (13) based on the condition shown by Eq. (12). ${ }^{13)}$

Where, $\mathrm{P}_{\mathrm{i}}$ is the partial pressure of component $\mathrm{i}, \mathrm{K}_{\mathrm{n}}$ is the equilibrium constant of Eq. (n), $\mathrm{H}^{0}$ is the enthalpy of gas and $\Delta \mathrm{H}_{298}^{0}$ is the formation energy of propane. The subscript $r$ means a reaction product, and $\mathrm{p}$ means a product. The equilibrium constants of each reaction and the enthalpy of each gas were obtained from JANAF Thermochemical Tables. ${ }^{14)}$

$$
\begin{aligned}
& \mathrm{CO}_{2} \Leftrightarrow \mathrm{CO}+\frac{1}{2} \mathrm{O}_{2} \quad\left(K_{7}=\frac{P_{\mathrm{CO}} \cdot P_{\mathrm{O}_{2}}{ }^{1 / 2}}{P_{\mathrm{CO}_{2}}}\right) \ldots \ldots \ldots . . . \\
& \mathrm{H}_{2} \mathrm{O} \Leftrightarrow \mathrm{H}_{2}+\frac{1}{2} \mathrm{O}_{2} \quad\left(K_{8}=\frac{P_{\mathrm{H}_{2}} \cdot P_{\mathrm{O}_{2}}{ }^{1 / 2}}{P_{\mathrm{H}_{2} \mathrm{O}}}\right) \\
& \mathrm{H}_{2} \mathrm{O} \Leftrightarrow \frac{1}{2} \mathrm{H}_{2}+\mathrm{OH} \quad\left(K_{9}=\frac{P_{\mathrm{OH}} \cdot P_{\mathrm{H}_{2}}{ }^{1 / 2}}{P_{\mathrm{H}_{2} \mathrm{O}}}\right) \\
& \frac{1}{2} H_{2} \Leftrightarrow H \quad\left(K_{10}=\frac{P_{H}}{P_{H_{2}}^{1 / 2}}\right) \\
& \frac{1}{2} O_{2} \Leftrightarrow O \quad\left(K_{11}=\frac{P_{O}}{P_{O_{2}}^{1 / 2}}\right) \\
& P_{C O}+P_{C_{2}}+P_{O_{2}}+P_{H_{2}}+P_{\mathrm{H}_{2} \mathrm{O}}+P_{\mathrm{OH}}+P_{\mathrm{H}}+P_{\mathrm{O}}=1 \mathrm{~atm} \ldots \\
& \left(H^{0}-H_{298}^{0}\right)_{p}=\left(H^{0}-H_{298}^{0}\right)_{r}-\Delta H_{298}^{0}
\end{aligned}
$$

Heat transfer from the high temperature gas to a particle was calculated from the heat balance in Eq. (14), assuming the particle to be a single particle and considering radiant heat transfer and convective heat transfer from the gas. Equation (15) shows the convective heat transfer term, and Eq. (16) shows the radiant heat transfer term. Assuming hypothetically that the particle is spherical in shape, the Nusselt number $\mathrm{Nu}$ of the convective heat transfer term was calculated by using the Ranz-Marshall's formula ${ }^{15)}$ shown in Eq. (17). Since the particle diameter is small, the internal temperature in the particle is assumed to be uniform, and it is also assumed that the surface area of the single particle is extremely small in comparison with the radiation area of the high temperature gas. The particle diameter used in the calculation was $200 \mu \mathrm{m}$, and the density, specific heat, emissivity, and thermal conductivity of the particle were assumed to be constant. The physical properties used in the calculation are shown in Table 2. The specific heat $c_{p, P}$ and the density $\rho_{\mathrm{P}}$ of chromium ore are the weighted averages of the specific heats ${ }^{16)}$ and the densities ${ }^{17)}$ of oxides, respec-

Table 2. Parameters used for estimation of burner and particle temperatures.

\begin{tabular}{ccc}
\hline $\mathrm{c}_{\mathrm{p}, \mathrm{P}}$ & 920 & $\mathrm{~J} /\left(\mathrm{kg} \cdot{ }^{\circ} \mathrm{C}\right)$ \\
$\rho_{\mathrm{P}}$ & 4800 & $\mathrm{~kg} / \mathrm{m}^{3}$ \\
$\varepsilon_{\mathrm{p}}$ & 0.8 & $(-)$ \\
$\lambda$ & 0.03 & $\mathrm{~W} /\left(\mathrm{m} \cdot{ }^{\circ} \mathrm{C}\right)$ \\
\hline
\end{tabular}

tively, in the chromium ore. The contents of each oxide in chromium ore were calculated for the $\mathrm{Cr}$ component as $\mathrm{Cr}_{2} \mathrm{O}_{3}$, for the $\mathrm{Fe}$ component as $\mathrm{FeO}$ and for others as $\mathrm{MgO}$ and $\mathrm{Al}_{2} \mathrm{O}_{3}$ from analytical values. As the emissivity $\varepsilon_{\mathrm{P}}$ of chromium ore, that of $\mathrm{Cr}_{2} \mathrm{O}_{3}$ was used. ${ }^{18)}$ The thermal conductivity $\lambda$ of the produced gas was a weighted average of the thermal conductivities ${ }^{19)}$ of $\mathrm{CO}_{2}$ and $\mathrm{H}_{2} \mathrm{O}$.

$$
\begin{aligned}
& m c_{p, P} \frac{d\left(T_{p}\right)}{d t}=A_{S, P} \cdot q_{P}+A_{S, P} \cdot q_{R} \\
& q_{P}=\frac{N u \lambda}{d}\left(T_{g}-T_{P}\right) \\
& q_{R}=\varepsilon_{P} \cdot \sigma\left(T_{g}^{4}-T_{P}^{4}\right) \\
& N u=2+0.6 \operatorname{Re}_{P}^{1 / 2} \operatorname{Pr}^{1 / 3}
\end{aligned}
$$

Where, $\mathrm{m}$ is the mass of a particle, $\mathrm{d}$ is the particle diameter, $T_{P}$ is the temperature of the particle, $T_{g}$ is the temperature of the combustion gas, $\mathrm{A}_{\mathrm{S}, \mathrm{P}}$ is the surface area of the particle, $c_{p, P}$ is the specific heat of the particle, $\varepsilon_{\mathrm{P}}$ is the emissivity of the particle, $\lambda$ is the thermal conductivity of the gas, $\mathrm{q}_{\mathrm{P}}$ is convective heat transfer between the combustion gas and particle, $\mathrm{q}_{\mathrm{R}}$ is radiant heat transfer between the combustion gas and particle, $\mathrm{Nu}$ is the Nusselt number, $\mathrm{Re}$ is the Reynolds number and Pr is the Prandtl number of the gas.

The above equations were computed by the fourth-order Runge-Kutta method, and the behaviors of the particle temperature and combustion gas temperature were calculated. In this calculation, only heat transfer between the combustion gas and the particle was considered. Heat transfer with the outside of the system was not considered.

Since the initial velocities of both the particle and the gas from the burner nozzle were assumed as equivalence, the Reynolds number of the particle $R_{\text {ep }}$ was 0 . Furthermore, since the lance height was $1.5 \mathrm{~m}$, which was the same condition as in the previous study, ${ }^{12)}$ the residence time of the ore particle in the burner flame was 0.1 second, which was shown in the previous study.

Figure 12 shows the relationship between the heated ore feed rate and the temperatures of the flame and the chromium ore particle. Under the condition in which the heated

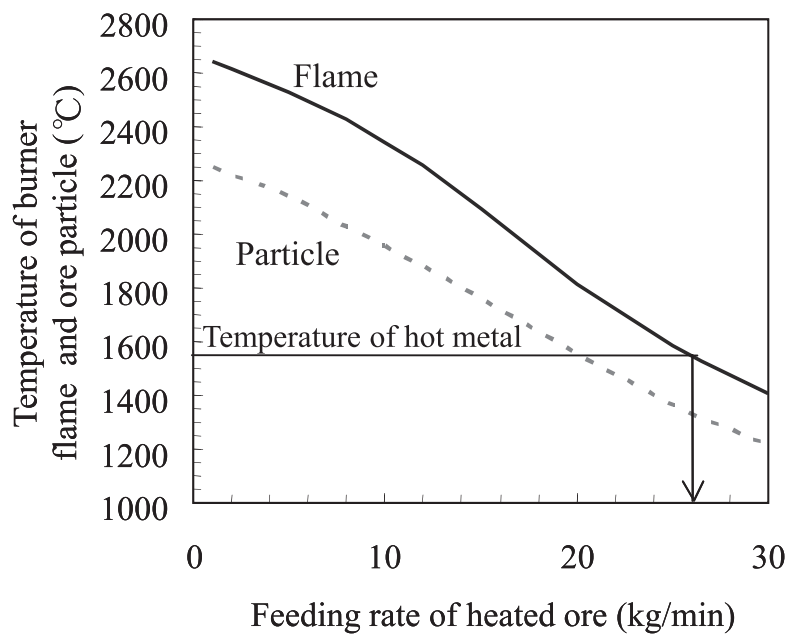

Fig. 12. Calculated temperatures of burner flame and ore particle against feeding rate of heated ore. 


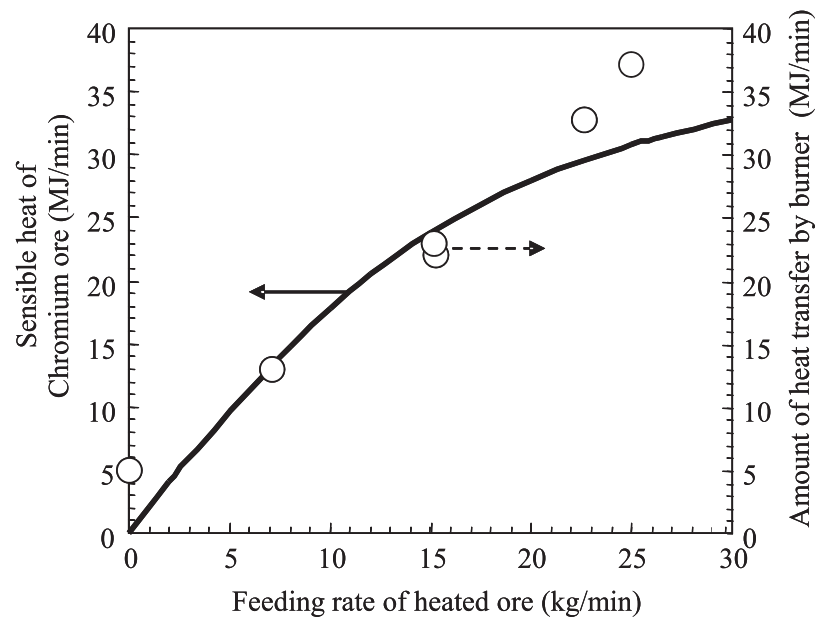

Fig. 13. Calculated sensible heat of chromium ore and amount of heat transfer by burner against feeding rate of heated ore.

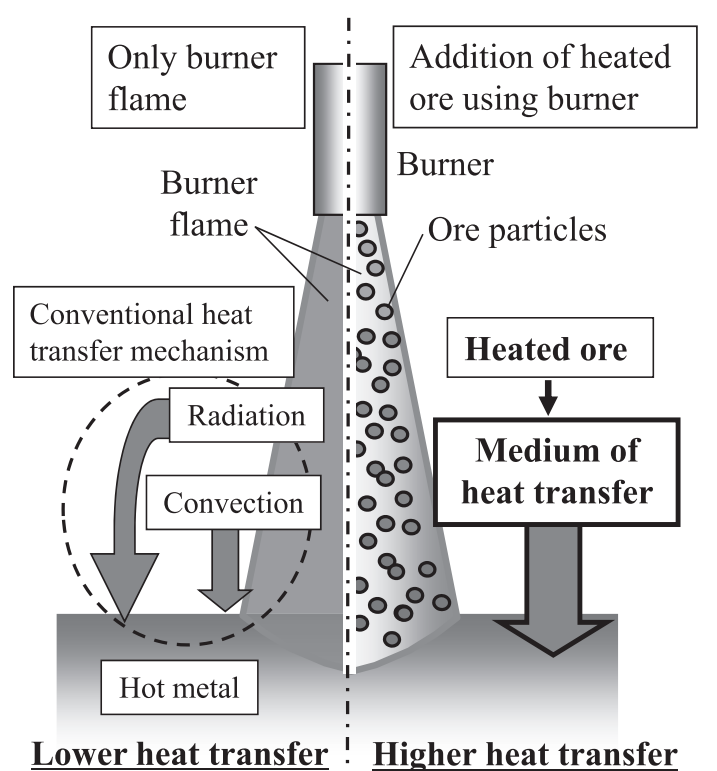

Fig. 14. Schematic diagram of heat transfer mechanism by heated ore addition using burner.

ore feed rate is $26 \mathrm{~kg} / \mathrm{min}$, the temperature of the burner flame and the hot metal are identical. This is approximately consistent with above-mentioned result that the heated ore feed rate is $26.5 \mathrm{~kg} / \mathrm{min}$ when the burner combustion heat transfer ratio reaches $100 \%$.

Figure 13 shows the calculated total sensible heat of the chromium ore shown in Fig. 12 and the amount of heat transfer by the burner against the heated ore feeding rate. The calculated total sensible heat of the chromium ore is based on the assumption that the temperatures of all particles are the same. However, the temperature of the ore particles decreases with the heated ore feeding rate, and the total sensible heat of the chromium ore increases due to the increased amount of chromium ore, which was the same as shown in the previous study. ${ }^{12)}$

When the heated chromium ore feeding rate is zero, the heat from the burner flame is transferred to the hot metal and slag by radiation and convection from the flame.

On the other hand, when feeding heated ore through the burner, the amount of heat transfer by burner combustion heat obtained from the experimental results is generally consistent with the calculated sensible heat of the chromium ore. In other words, the heat transfer of the sensible heat of the chromium ore is the dominant mechanism of heat transfer between burner combustion and the hot metal and slag.

Figure 14 shows the schematic diagram of the heat transfer mechanism with the heated ore feeding method using the burner.

From the above results, the ore particles heated by the flame function as a medium of heat transfer from the flame to the hot metal and slag, and it is possible to transfer the heat of burner combustion to the hot metal more efficiently by the heated ore than by post-combustion or only the burner flame.

This method makes it possible not only to increase the amount of heat transfer, but also to decrease the thermal load on the refractory by optimizing the feeding rate of heated ore.

\section{Application for Heated Ore Addition Lance Using Burner to 185 Ton Actual Smelting Reduction Fur- nace}

Based on the 5 ton converter tests, the heated ore addition lance using the burner was applied to an actual smelting reduction furnace, which is a top and bottom blowing converter, at JFE Steel's East Japan Works (Chiba).

The burner lance was used during the smelting reduction period in the same manner as in the 5 ton converter tests. The total flow rate of oxygen gases, which comprised the top blown gas, bottom blown gas and the combustion improver of the burner, was equal to the total flow rate without the burner. The flow rate of the bottom blown oxygen was the same as that in conventional operation, and the flow rate of the top blown oxygen was reduced by the amount of oxygen blown as the burner combustion improver. The amount of carbonaceous material was also reduced corresponding to the decrease in top blown oxygen during the smelting reduction period with the burner. The lance height of the burner lance was the same as that of the main lance. As in the 5 ton converter tests, the fuel gas was propane. All chromium ore was fed to the converter through the burner lance.

Figure 15 shows the relationship between the ratio of the heated ore feeding rate/burner calorific power and the heat efficiency of the burner calorific power.

From the results of the 5 ton converter tests, the ratio of the heated ore feeding rate/burner calorific power in the actual converter was adjusted to be more than $0.5 \mathrm{~kg} / \mathrm{MJ}$ so that the heat efficiency of the burner was more than $75 \%$ in order not to increase the thermal load on the refractory, which was shown in Fig. 10. As in the tests with the 5 ton converter, the heat transfer efficiency of burner combustion with addition of heated ore was $80-90 \%$.

Figure 16 shows the relationship between the amount of chromium ore and the energy supplied to the furnace. The supplied energy is the sum of the heat generated by the decarburization reaction, post-combustion and burner combustion. The supplied energy per unit of chromium ore added to the furnace decreased by $17 \%$ at the same amount of total supplied oxygen gas, confirming that more efficient heat transfer is also achieved by the heated ore addition lance using the burner in operation with an actual converter. 


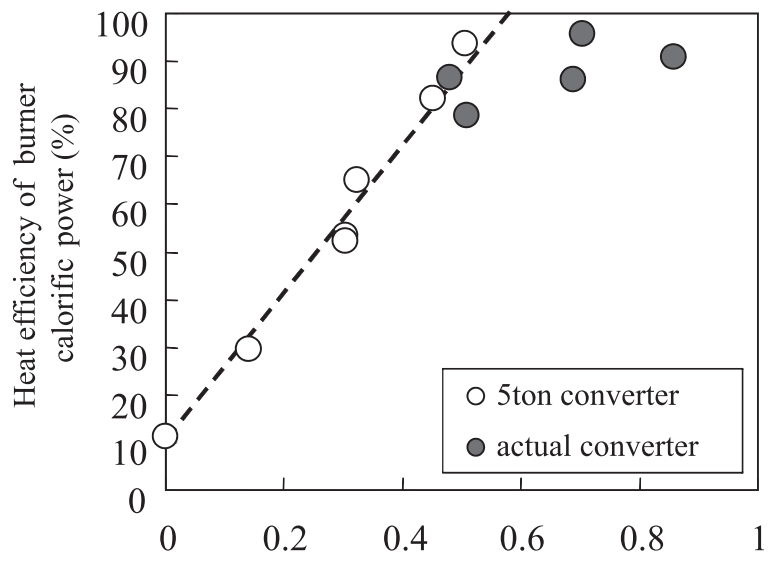

Heated chromium ore / burner calorific power ( $\mathrm{kg} / \mathrm{MJ}$ )

Fig. 15. Relationship between heated ore feeding rate/burner calorific power and heat efficiency of burner calorific power.

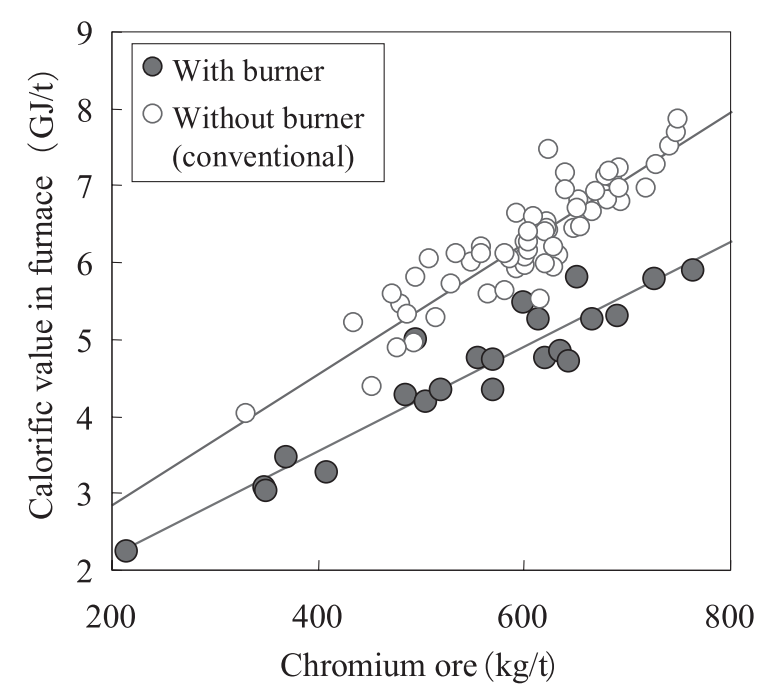

Fig. 16. Relationship between chromium ore feeding rate and energy supplied to furnace.

\section{Conclusions}

In order to increase the thermal margin and the heat efficiency of the chromium ore smelting reduction furnace, a heated ore addition technology using a lance equipped with a burner in the converter was developed and applied to the actual process.

The results are summarized as follows:

(1) In tests with a 5 ton converter, the amount of effective heat transfer increased by $18 \%$ with addition of heated ore using the burner compared with the conventional process (without the burner), which corresponded to a conventional top and bottom blown converter.

(2) The superheat (unknown heat) decreased as the heated ore feeding rate increased in the 5 ton converter. At heated ore feeding rates of more than $20 \mathrm{~kg} / \mathrm{min}$ using the burner, the superheat with ore addition was lower than that of the conventional process.

(3) Depending on the increase in the heated ore feeding rate, a decrease in the off-gas temperature and a reduction the thermal load on the refractory were confirmed in the 5 ton converter.

(4) The heat transfer ratio of burner combustion with addition of heated ore increased up to $94 \%$, depending on the increase of the heated ore feeding rate in the 5 ton converter.

(5) Since the amount of effective heat transfer of burner combustion heat was generally consistent with the calculated value of the total sensible heat of the chromium ore particles, the ore particles heated by the flame function as a medium of heat transfer from the burner flame to the molten metal and slag.

(6) Based on the above-mentioned results of the 5 ton converter tests, this technology was applied to an actual smelting reduction furnace at JFE Steel's East Japan Works (Chiba). As in the tests with the 5 ton converter, the heat transfer efficiency of burner combustion with addition of heated ore was about $90 \%$. In the actual converter test, the supplied energy per unit of chromium ore added to the furnace decreased by $17 \%$ at same amount of total supplied oxygen gas.

\section{REFERENCES}

1) K. Taoka, C. Tada, S. Yamada, H. Nomura, M. Ohnishi and H. Bada: Tetsu-to-Hagané, 76 (1990), 1863.

2) Y. Kishimoto, K. Taoka and S. Takeuchi: Kawasaki Steel Giho, 28 (1996), 213.

3) Y. Kaneko and M. Osame: JFE Giho, 20 (2008), 79.

4) S. Takeuchi, H. Nakamura, T. Sakuraya, T. Fujii and T. Nozaki: Tetsu-to-Hagané, 76 (1990), 1847.

5) M. Matsuo, C. Saito, H. Katayama, H. Hirata and Y. Ogawa: Tetsuto-Hagané, 76 (1990), 1871.

6) M. Matsuo, C. Saito, H. Katayama, H. Hirata, M. Kanemoto and T. Ibaragi: Tetsu-to-Hagané, 76 (1990), 1879.

7) M. Hirai, R. Tsujino, T. Mukai, T. Harada and M. Oomori: Tetsu-toHagané, 73 (1987), 1117.

8) N. Takashiba, M. Nira, S. Kojima, H. Take and F. Yoshikawa: Tetsuto-Hagané, 75 (1989), 89.

9) A. Shinotake and Y. Takamoto: Rev. Metall., 24 (1993), 965.

10) K. Takahashi, Y. Tanabe, K. Iwasaki, M. Muroya, I. Kikuchi and M. Kawakami: Tetsu-to-Hagané, 76 (1990), 1887.

11) Y. Kato, J. Grosjean and J. Reboul: Tetsu-to-Hagané, 75 (1989), 478.

12) G. Okuyama, F. Ogasawara, Y. Uchida, Y. Kishimoto and Y. Miki: Tetsu-to-Hagané, 98 (2012), 627.

13) Y. Mizutani: Combustion Engineering, 3rd ed., Morikita Publishing Co., Ltd., Tokyo, (2006), 71.

14) D. R. Stull and H. Prophet: JANAF Thermochemical Tables 2nd Ed., National Standard Reference Data System, Washington, DC, (1971).

15) W. E. Ranz and W. R. Marshall: Chem. Eng. Prog., 48 (1952), 141.

16) Y. S. Touloukian and E. H. Buyco: Thermophysical Properties of Matter Vol. 5, Specific Heat Nonmetallic Solid, Plenum, New York, (1970).

17) R. E. Krzhizhanovskii: Thermal Physical Properties of the Oxide, Japan and the Soviet News Agency, Wakayama, (1975).

18) Y. S. Touloukian and D. P. DeWitt: Thermophysical Properties of Matter Vol. 8, Thermal Radiative Properties of Nonmetallic Solid, Plenum, New York, (1972).

19) Y. S. Touloukian, P. E. Liley and S. C. Saxena: Thermophysical Properties of Matter Vol. 3, Thermal Conductivity of Nonmetallic Liquids and Gases, Plenum, New York, (1970). 